\section{LAKE BALATON.}

I AKE BALATON, or Platten See, is the largest L lake in Austro-Hungary, and, in fact, in southeastern Europe. It is fifty miles long, and is shallow in proportion to its size. It lies in a depression on the Hungarian plain at the foot of the hills of the Bakony Wald. The Hungarian Geographical Societv organised a commission, under the presidency of Prof. Ludwig von Loczy, to subject this lake to a thorough investigation. The results are being published in three volumes, of which the first is devoted to geography, geology, palæontology, hydrography, physics, and chemistry; the second to biology; the third to the social and ethnographical geography, including accounts of the watering-places and hot springs, and a bibliography. Four further sections of this work have now been received, and one of them completes the second volume. As the parts are issued in the order of their completion, it is not easy to form from these disconnected fragments a clear impression of the work as a whole. Thus the only contribution yet issued to the introduction, which is to be a geographical memoir on the lake and its district, is a geo - physical appendix. dealing with the determination of gravity by R. von Sterneck, with the influence of variations in gravity on the level of $t \mathrm{he}$ lake surface by Baron Lorand Eötvös, and a report on the magnetic observations by Dr. L. Steiner.

Dr. von Sterneck's results show that gravity is normal over part of the middle of the lake, while it is above normal along a beit of the hills to the north, and it is below normal in a band still further to the north.

Baron Eötvös has deternined the relations of the

1 "Resultate der Wissenschaftlichen Untersuchungen des Balaton." Vol. i., Physische Geographie des Balatonsees und seiner Umgebung: P irt i., Die Geomorphologie des Balatonsees und seiner Umgebung, Section iii, Ge ,physikalischer Anhang i. (I.) R. v. Sterneck, Untersuchungen über die S :hwerkraft; pp. 3r, I map; (II.) Baron L. Eötvös, Die Niveaufläche des Balatonses und die Veränderungen der Schwerkraft auf diesem, pp. 6 , 27 figs.; (III.) L. Steiner, Erdmagnetische Messungen in Sommer Igrr, pp. 30, 6 figs. Price 6 kroner. Part v., Die Physikalischen Verhältnisse des Wassers des B ala kroes. S pp. Ir 4 , xxi. plates, r22 figs. Price ro kroner. Vol. ii., Die Biolozie des pp. Ir4, xxi. plates, 122 figs. Price ro kroner. Vol. ii., Die Biolozie des Balatonsees und seiner Umgebung: Part 11., Die Flora, Section i1, Die Pfanzengeographischen Verhältnisse der Balatonsee-gegend, appendix : A. Lovassy, Die Tropischen Nymphæen des Heviz iees bei Keszthely, pp. roo, iv p'ates, 25 figs. Price ro kroner. Vol. iii., Soziologische und Anthropologische Geographie der Umgebung des Balaton: Part i., Geschichte der Ungebung des Balaton, Division iii., R. BÉkefi, Kirchen und Burgen in der Umgebung

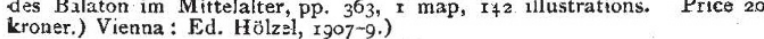
NO. 2 I 32 , VOL. 84$]$ variations in gravity to the level of the lake surface by measurements made on the ice during the winter. His observations were interrupted by the mild winter of 1902 , when the lake was inadequately frozen. His results show that Lake Balaton occurs along a tectonic line, and he recognises variations in level due to gravity, similar to those in India, but on a smaller scale. Dr. Steiner has determined the various magnetic elements for the area of the lake, and has investigated the magnetic properties of the rocks.

No other locality in Europe is so convenient for the study of the formation of wide ice-sheets on an inland sea as Lake Balaton, for, in spite of the comparative saltness of the water, its surface is more completely frozen than the Swiss lakes, which being much deeper, therefore cool more slowly. In ordinary winters the whole of Lake Balaton is covered over with a firm ice-sheet. Dr. von Cholnoky has made a detailed study of the ice in all stages of its formation and decay, illustrated by numerous excellent photo- 
springs, so that the temperature of the water is from $32^{\circ}$ to $38^{\circ} \mathrm{C}$. in summer, and from $26^{\circ}$ to $30^{\circ} \mathrm{C}$. in winter. A chapter on the composition of the lake water, by G. v. Weszelszky, shows that it contains 0.531 part per thousand of salts, of which the chief are magnesium chloride, bicarbonate of lime, and sodium sulphate. The shape of the lake basin has been carefully determined by Dr. Jordan.

Dr. Lovassy has attempted to acclimatise tropical water-lilies in this pond. $\mathrm{He}$ points out the interesting fact that the Nile lotus (Nymphaea lotus) is still living in the warm waters of Nagyvared, and a flower stem referred to this plant was discovered in Upper Pliocene calcareous tufa at Ganocz, in Szepes, by Prof. Pax, of Breslau, in 1904. Dr. Lovassy, therefore, holds that the Nile lotus still lives in Hungary

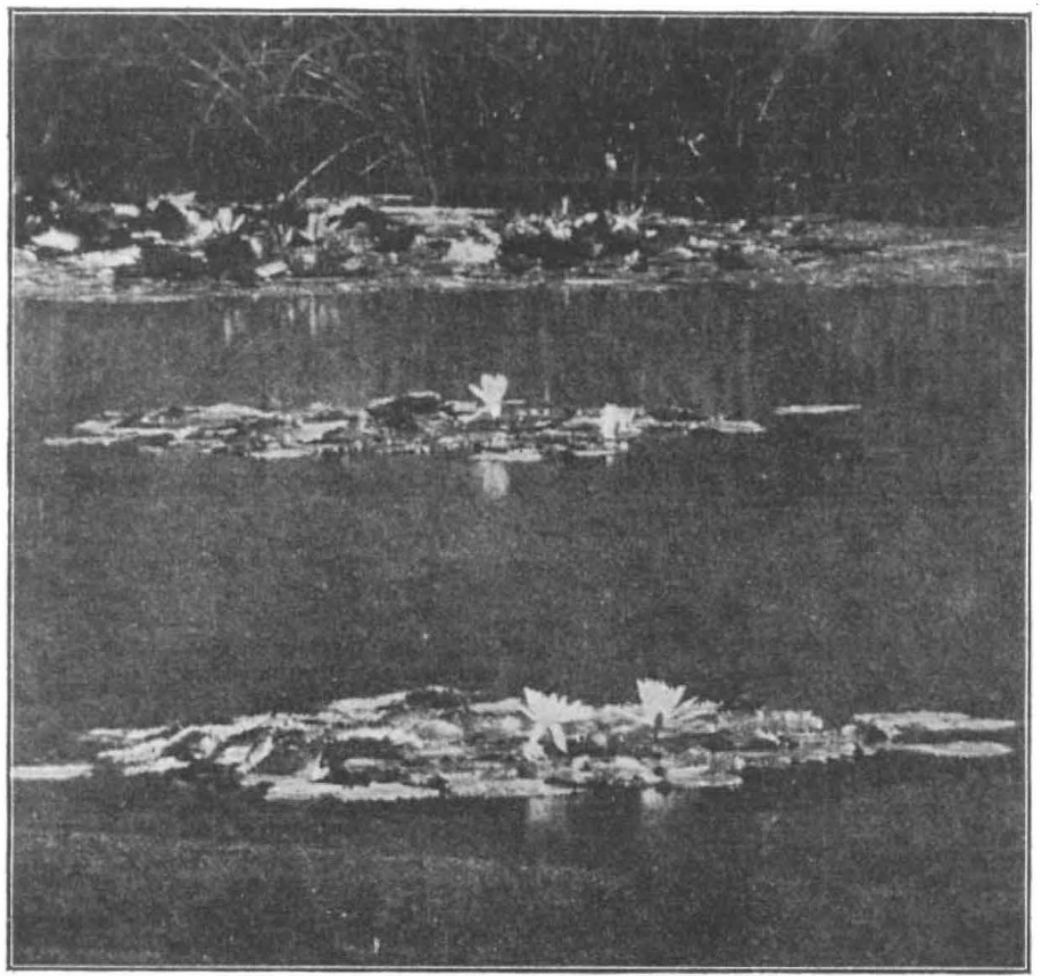

FIG 2.-Water-lilies in the Hévizsee. In foreground some specimens of Nymphaea lotus, L., and in background Nymphaea rubra longifiora, nov. subsp.

as a relic from its former wide extension over southern Europe. He insists that the plant was neither introduced by man nor birds, and that Nagyvared is a natural subtropical oasis. Earlier attempts to plant tropical water-lilies in the Hévizsee were made between 1826 and 1842 . Dr. Lovassy's experiments lasted. from 1898 to 1906 , and were tried on many distinct species; and in connection with the work he has compiled a synopsis of the Nymphaceæ; some species failed altogether, others lived, but would not produce seeds, and only a variety of the Indian Nymphaea rubra, for which he founds a new subspecies, longiflora, has been successfully acclimatised.

The longest of the four contributions recently received is a memoir by Dr. Békefi on the mediæval churches and castles in the neighbourhood of Lake Balaton. It consists of a detailed account illustrated by plans and photographs, both of the buildings still occupied and those represented by numerous picturesque ruins.

$$
\text { NO. } 2 \text { I } 32 \text {, VOL. 84] }
$$

THE BRITISH ASSOCIATION AT SHEFFIELD.

F ROM the point of view of numbers, this year's meeting of the British Association, with a total membership of about 1400 , does not take a very high place among the great meetings of recent years; nevertheless, there is only one opinion as to its success. The arrangements have been admirably made, and everyone agrees that no more perfect and convenient place for the reception-room and accessory writing and other rooms could have been provided than has been furnished at the Cutlers' Hall. The local committee, under the chairmanship of Prof. W. M. Hicks, is to be congratulated upon the businesslike way in which it has organised the mary and various general affairs of the meeting. The scientific proceedings of the sections have been full of interest, but here no further reference need be made to them, as accounts of the work of the sections will appear in later issues.

The annual report of the council of the association was presented at the meeting of the general committee on August 3I. The council presented an address to the King upon his accession to the throne, and in a further letter expressed the hope that he would follow his august father in the patronage of the association. This the King has consented to do.

At the Winnipeg meeting last year a resolution was formulated by the Anthropological Section, relating to inquiries into Canadian ethnology, was supported by the general committee, and referred to the council. This resolution, which was forwarded to the Dominion Government by the council was as follows :-

I. (I) "That it is essential to scientific knowledge of the early history of Canada that full and accurate records should be obtained of the physical character, geographical distribution and migrations, languages, social and political institutions, native arts, industries, and economic systems of the aboriginal peoples of the country.

(2) "That scientific knowledge of the principles of native design and handicraft is an essential preliminary to any development of native industries such as has already been found practicable, especially in the United States, in Mexico, and in India, and that such knowledge has also proved to be of material assistance in the creation of national schools of design among the white population.

(3) "That, in the rapid development of the country, the native population is inevitably losing its separate existence and characteristics.

(4) "That it is therefore of urgent importance to initiate, without delay, systematic observations and records of native physical types, languages, beliefs, and customs ; and to provide for the preservation of a complete collection of examples of native arts and industries in some central institution, and for public guardianship of prehistoric monuments such as village sites, burial grounds, mounds, and rock carvings.

(5) "That the organisation necessary to secure these objects, and to render the results of these inquiries accessible to students and to the public, is such as might easily be provided in connection with the National Museum at Ottawa, which already includes many fine examples of aboriginal arts and manufactures, and might be made a 